\title{
BLOOD SERUM BIOOHEMICAL VALUES OF MOUNTAIN REEDBUCKS (REDUNCULA FULVORUFULA): VARIATIONS WITH SEX AND SEASON
}

\author{
J. VÁHALA, J. POSPÍŠIL*, R. POKORNÝ and F. KAŠE \\ East-Bohemian Zoological Garden, 55401 Dvůr Králové nad Labem \\ Department and Institute of Biophysics, Faculty of Medicine, Charles University, Prague
}

Received May 18, 1990

\begin{abstract}
Váhala J., J. Pospíšil, R. Pokorný, F. Kaše: Blood Serum Biochemical Values of Mountain Reedbucks (Reduncula fulvorufula): Variations with Sex and Season. Acta vet. Brno, 60, 1991: 143-148.

Repeated biochemical examination of the blood sera of 17 clinically healthy mountain reedbucks (Reduncula fulvorufula), 4 males and 13 females, showed higher mean magnesium values and lower mean potassium values in winter (1st November 30th March) than in summer (1st May - 30th September).

Comparison of the blood serum biochemical values obtained in males and females showed a higher alkaline phosphatase activity in males.

The remaining blood serum biochemical values under study (total protein, glucose, creatinine, cholesterol, urea, calcium, phosphorus, chloride and sodium level and aspartate aminotransferase (AST) and alanine aminotransferase (ALT) activity showed no significant variation with either sex or season.
\end{abstract}

Mountain reedbuck, blood serum, biochemistry, season, sex

In our previous reports (Pospíšil and Pradáč 1984; Váhala et al. 1989) we presented the results of biochemical examination of the blood sera of 7 female and 1 male clinically healthy mountain reedbuck (Reduncula fulvorufula) kept in the Eest-Bohemian Zoological Garden. The present study provides more detailed information on the blood serum biochemical values of male and female mountain reedbucks in relation to sex and season.

\section{Materials and Methods}

In 1980-1988 repeated blood serum biochemical examinations were carried out in 17 adult mountain reedbucks (Reduncula fulvorufula), 4 males and 13 females over two years of age, kept in the East-Bohemian Zoological Garden, on the occasion of regular preventive veterinary treatments such as hoof trimming. Blood samples were withdrawn from the vena jugularis of manually restrained animals in summer (1st May - 30th September) and winter (1st November - 30th March).

In winter the animals were housed in heated pens with the possibility of entering open-air enclosures (depending on weather conditions) and were fed, ad libitum, hay supplemented with $0.1 \mathrm{~kg}$ ZOO I granules, $0.1 \mathrm{~kg}$ alfalfa granules and $0.15 \mathrm{~kg}$ oat-flakes per animal per day. In summer they were kept in open-air enclosures with shelters and fed grass supplemented as in winter.

Blood samples were collected into glass test tubes and were allowed to stand at laboratory temperature for 60 minutes. Afterwards they were centrifuged to obtain blood sera. Biochemical

* Doc. MVDr. J. Pospísil, DrSc., deceased May 10, 1990 


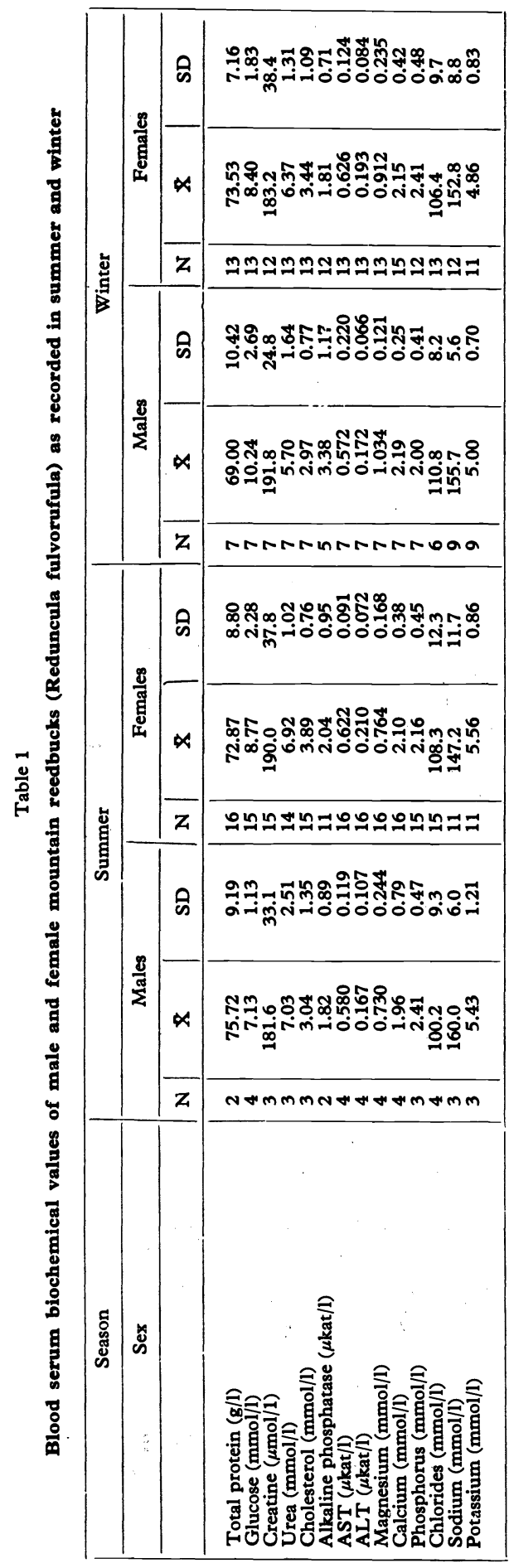

examination of the blood sera was carried as described previously (Pospisil et al. 1987). It covered total protein, glucose, creatinine, urea, cholesterol, magnesium, calcium, phosphorus, chloride, sodium and potassium level and alkaline phosphatase, aspartate aminotransferase (AST) and alanine aminotransferase (ALT) activity.

Means and standard deviations were computed for the individual groups. Significance of the differences between the means was assessed by Student's t-test.

\section{Results}

The results of biochemical examination of the blood sera of male and female mountain reedbucks obtained in summer and winter are presented in Table 1 . The examinations conducted in summer showed no significant differences of the means between males and females. In winter the only significant $(\alpha \leq 1)$ difference between the means obtained for males and females was recorded for cholesterol. In females no significant differences were found between the mean values obtained in summer and those obtained in winter. In males, on the other hand, a significant $(\alpha \varepsilon<1.5>)$ difference between the means obtained in summer and winter was recorded for magnesium level. In spite of these differences between some summer and winter blood serum

biochemical values of males the E values for males were pooled and compared with the pooled values recorded for females ( Table 2). Similarly, blood serum biochemical values of males and females obtained in summer were pooled (Table 3 ) and the differences between the pooled means were assessed statistically z $x$ किष्य 
Table 2

Blood serum biochemical values of mountain reedbucks (Reduncula fulvorufula): variations with sex

\begin{tabular}{|c|c|c|c|c|c|c|c|c|}
\hline \multicolumn{2}{|l|}{ Sex } & \multicolumn{3}{|c|}{ Males } & \multicolumn{3}{|c|}{ Females } & \multirow{2}{*}{$\dot{\omega}$} \\
\hline & . & $\mathbf{N}$ & 8 & SD & $\mathbf{N}$ & 8 & SD & \\
\hline $\begin{array}{l}\text { Total protein }(\mathrm{g} / \mathrm{l}) \\
\text { Glucose }(\mathrm{mmol} / \mathrm{l}) \\
\text { Creatinine }(\mu \mathrm{mol} / \mathrm{l}) \\
\text { Urea }(\mathrm{mmol} / 1) \\
\text { Cholesterol (mmol/l) } \\
\text { Alkaline phosphatase }(\mu \mathrm{kat} / \mathrm{l}) \\
\text { AST }(\mu \mathrm{kat} / \mathrm{l}) \\
\text { ALT }(\mu \mathrm{kat} / \mathrm{l}) \\
\text { Magnesium }(\mathrm{mmol} / \mathrm{l}) \\
\text { Calcium }(\mathrm{mmol} / \mathrm{l}) \\
\text { Phosphorus }(\mathrm{mmol} / \mathrm{l}) \\
\text { Chlorides (mmol/l) } \\
\text { Sodium (mmol/l) } \\
\text { Potassium }(\mathrm{mmol} / \mathrm{l})\end{array}$ & $\vdots$ & $\begin{array}{r}9 \\
11 \\
10 \\
10 \\
10 \\
7 \\
11 \\
11 \\
11 \\
13 \\
10 \\
10 \\
12 \\
12\end{array}$ & $\begin{array}{c}70.44 \\
9.11 \\
188.8 \\
6.09 \\
2.99 \\
2.92 \\
0.575 \\
0.162 \\
0.923 \\
2.124 \\
2.128 \\
106.6 \\
148.5 \\
5.109\end{array}$ & $\begin{array}{c}10.01 \\
2.68 \\
26.0 \\
1.90 \\
0.90 \\
1.26 \\
0.183 \\
0.073 \\
0.224 \\
0.462 \\
0.452 \\
9.8 \\
30.2 \\
0.819\end{array}$ & $\begin{array}{l}29 \\
28 \\
27 \\
27 \\
28 \\
23 \\
29 \\
29 \\
29 \\
31 \\
27 \\
28 \\
23 \\
22\end{array}$ & $\begin{array}{c}73.17 \\
8.73 \\
187.0 \\
6.65 \\
3.68 \\
1.92 \\
0.624 \\
0.208 \\
0.827 \\
2.125 \\
2.276 \\
107.4 \\
150.2 \\
5.215\end{array}$ & $\begin{array}{c}7.97 \\
2.13 \\
37.5 \\
1.18 \\
0.94 \\
0.82 \\
0.105 \\
0.077 \\
0.183 \\
0.401 \\
0.476 \\
11.0 \\
10.4 \\
0.900\end{array}$ & $\begin{array}{l}1 \\
! \\
! \\
! \\
1 \\
5 \\
1 \\
1 \\
1 \\
1 \\
! \\
1 \\
1 \\
1\end{array}$ \\
\hline
\end{tabular}

N $=$ No. animals examined

$\mathrm{X}$ mean value

SD $=$ standard deviation of the mean

Sig. = significance of the differences of the means (\%)

Symbol 1 stands for $\alpha \leqq 1$

Symbol 5 stands for $\alpha \varepsilon(1.5>$

Symbol/stands for $\alpha>5$

AST = aspartate aminotransferase

$\mathrm{ALT}=$ alanine aminotransferase

from Table 2, a significantly ( $\alpha \varepsilon<1.5>$ ) lower value in females than in males was found for alkaline phosphatase activity. The differences in the remaining blood serum biochemical values between males and females were not significant. Comparison of the mean biochemical values obtained in summer and winter ( $\mathrm{Ta}$ ble 3 ) showed a significantly $(\alpha \leq 1)$ lower mean value for magnesium and a significantly $(a \varepsilon<1.5>)$ higher mean value for potassium in summer.

\section{Discussion}

Comparison of the blood serum biochemical values of mountain reedbucks recorded in winter and summer showed a significantly lower magnesium level and a significantly higher potassium level in summer than in winter. In winter the animals were fed hay. In summer they received green fodder of varying quality (occasionally also mixed corn grown rapidly by means of fertilizers). According to Georgievskij et al. (1982) both $\mathrm{Mg}$ and $\mathrm{K}$ levels in the blood depend on their quantities in the ration, and where potash and nitrogen fertilizers are used, $\mathrm{Mg}$ content of the feed is reduced. Georgievskij et al. (1982) also reported that cows transferred to pasture had an increased blood level and that $\mathrm{Mg}$ content per $\mathrm{kg}$ dry matter was higher in hay than in grass. In the light of these observations the lower blood serum $\mathrm{Mg}$ level and the higher blook serum $\mathrm{K}$ level in summer than in winter as reported in the present study can be accounted for by the differences between summer and winter diet.

Alkaline phosphatase is an enzyme widespread in the body. According to Stogdale (1981) the range of its normal values in sheep and cattle is very wide and the diagnostic value of alkaline phosphatase is therefore rather low. In our study the blood serum alkaline phosphatase activity of mountain reedbucks was higher in males than in females. Similar findings were reported by Bush et al. 
Table 3

Blood serum biochemical values of mountain reedbucks (Reduncula fulvorufula): variations with season

\begin{tabular}{|c|c|c|c|c|c|c|c|}
\hline \multirow[t]{2}{*}{ Season } & \multicolumn{3}{|c|}{ Summer } & \multicolumn{3}{|c|}{ Winter } & \multirow{2}{*}{$\ddot{\infty}$} \\
\hline & $\mathbf{N}$ & $\mathrm{X}$ & SD & $\mathbf{N}$ & $\mathbf{X}$ & SD & \\
\hline $\begin{array}{l}\text { Total protein }(\mathrm{g} / \mathrm{l}) \\
\text { Glucose }(\mathrm{mmol} / \mathrm{l}) \\
\text { Creatinine }(\mu \mathrm{mol} / \mathrm{l}) \\
\text { Urea }(\mathrm{mmol} / \mathrm{l}) \\
\text { Chcl sterol }(\mathrm{mmol} / \mathrm{l}) \\
\text { Alkaline phosphatase }(\mu \mathrm{kat} / \mathrm{l}) \\
\text { AST }(\mu \mathrm{kat} / \mathrm{l}) \\
\text { ALT }(\mu \mathrm{kat} / \mathrm{l}) \\
\text { Magnesium }(\mathrm{mmol} / \mathrm{l}) \\
\text { Calcium }(\mathrm{mmol} / \mathrm{l}) \\
\text { Phosphorus }(\mathrm{mmol} / \mathrm{l}) \\
\text { Chlorides }(\mathrm{mmol} / \mathrm{l}) \\
\text { Sodium }(\mathrm{mmol} / \mathrm{l}) \\
\text { Potassium }(\mathrm{mmol} / \mathrm{l})\end{array}$ & $\begin{array}{l}18 \\
19 \\
18 \\
17 \\
18 \\
13 \\
20 \\
20 \\
20 \\
20 \\
18 \\
19 \\
14 \\
14\end{array}$ & $\begin{array}{c}73.16 \\
8.43 \\
188.6 \\
6.94 \\
3.75 \\
2.006 \\
0.612 \\
0.201 \\
0.757 \\
2.073 \\
2.208 \\
106.8 \\
150.0 \\
5.538\end{array}$ & $\begin{array}{l}8.61 \\
2.17 \\
36.3 \\
1.28 \\
0.98 \\
0.914 \\
0.095 \\
0.079 \\
0.178 \\
0.470 \\
0.456 \\
11.8 \\
11.9 \\
0.894\end{array}$ & $\begin{array}{l}20 \\
20 \\
19 \\
20 \\
20 \\
17 \\
20 \\
20 \\
20 \\
24 \\
19 \\
19 \\
21 \\
20\end{array}$ & $\begin{array}{c}71.85 \\
9.04 \\
186.4 \\
6.13 \\
3.28 \\
2.267 \\
0.625 \\
0.186 \\
0.955 \\
2.168 \\
2.263 \\
102.5 \\
154.0 \\
4.910\end{array}$ & $\begin{array}{l}8.46 \\
2.28 \\
33.4 \\
1.43 \\
0.99 \\
1.103 \\
0.165 \\
0.077 \\
0.208 \\
0.367 \\
0.490 \\
22.8 \\
7.6 \\
0.754\end{array}$ & 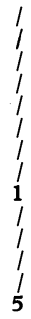 \\
\hline
\end{tabular}

$\mathbf{N}=$ No. animals examined

= mean value

SD = standard deviation of the mean

Sig. = significance of the difference of the means

Symbol 1 stands for $\alpha \leqq 1$

Symbol 5 stands for $\alpha \varepsilon(1.5>$

Symbol/stands for $\alpha>5$

AST $=$ aspartate aminotransferase

$\mathrm{ALT}=$ alanine aminotransferase

(1980) for giraffes. In scimitar-horned oryx, on the other hand, Bush et al. (1983) found no variations in alkaline phosphatase activity with sex. Eldirdiri et al. (1987), in their study on dromedary camels, found higher alkaline phosphatase levels in females. In view of these contradictory results and considering the small number of males examined in our study we conclude that the difference found by us between male and female mountain reedbucks are within the range of normal alkaline phosphatase activity of this species.

In general it can be concluded that the blood serum biochemical values of mountain reedbucks reported in the present study do not differ substantially from those found in our previous studies (Pospíšil and Pradáč 1984; Váhala et al. 1989) where the examinations were much smaller in number. To our knowledge, the only investigators concerned with blood serum biochemical parameters of mountain reedbucks abroad have been Drevemo et al. (1974) who reported only the values for calcium $(1.55 \pm 0.65 \mathrm{mmol} / \mathrm{l})$, phosphorus $(1.58 \pm$ $\pm 0.51 \mathrm{mmol} / \mathrm{l})$ and magnesium $(0.70 \pm 0.328 \mathrm{mmol} / 1)$. It should be added that their original data were expressed in terms of $\mathrm{mg} / 100 \mathrm{ml}$ and were converted by us to $\mathrm{mmol} / \mathrm{l}$ for the sake of comparison.

In conclusion let us draw attention the fact that our results were obtained by repeated examination of 17 animals ( 4 males and 13 females) and that particularly the numbers of males was very small and that the examinations were carried out over a period of several years during which changes could have occurred in both the internal (age) and external factors, thus affecting homeostasis of the individual animals, in consequence of which their blood serum biochemical values might have been modified. 


\section{Biochemické hodnoty krevního séra bahnivců horských (Reduncula fulvorufula) v závislosti na pohlaví a ročním období}

Opakovaným biochemickým vyšetřením krevního séra 17 klinicky zdravých bahnivců horských ( $R$ dunsula fulvorufula) -4 samců a 13 samic, byly zjištěny v zimním období (1. 11.-30. 3.) vyšší průměrné hodnoty hořčíku a nižší prüměrné hodnoty draslíku, než $\mathrm{v}$ období letním (1. 5. -30. 9.).

Při porovnání jednotlivých biochemických hodnot krevního séra samců s hodnotami samic byla $\mathrm{v}$ krevním séru samcủ zjištěna vyšší hodnota aktivity alkalické fosfatázy.

$\mathrm{Na}$ ostatní vyšetřované biochemické hodnoty krevního séra (hladiny celkových bílkovin, glukózy, kreatininu, cholesterolu, močoviny, vápníku, fosforu, chloridů sodiku a aktivity aspartátaminotransferázy /AST/ a alaninaminotransferázy /AST/ a alaninaminotransferázy /ALT/) nebyl zjištěn jak vliv ročního období, kdy byla zviŕata vyšetřována, tak vliv pohlaví vyšetřovaných zviřat.

\section{Биохимические величины кровяной сыворогки Reduncula fulvorufula в зависимости от пола и времени года}

Повторным биохчимическим исследованеим кровяной сыворотки 17 клинически здоровых особей Reduncula fulvorufula - 4 самцев и 13 самок - установили в зимний период (1 ноября - 30 марта) более высокие средние величины магния и более низкие средние величины по сравнению с летним периодом (1 мая - 30 сентября).

Сопоставляя отдельные биохимические величины сыворотки крови самцев с величинами самок, в кровяной сыворотке самцев установили более высокое значение активности щелочной фосфатазы.

По отношению к остальным исследуемым биохимическим величинам кровяной сыворотки (уровни общих белков, глюкозы, креатина, холеестерина, мочевины, кальция, фосфора, хлоридов, натрия и активности аспартатаминотрансферазы (AST) и аланинаминотрансферазы (ALT) не было установлено никакого влияние времени года, в течение которого проводились исследования животных, ни пола исследуемых животных.

\section{References}

BUSH, M.-CUSTER, R. S. - WHITLA, J. C.: Hematology and serum chemistry profiles for giraffes (Giraffa camelopardalis): Variations with sex, age, and restraint. J. Zoo Anim. Med., 11, 1980: $122-129$

BUSH, M.-CUSTER, R. S.-WHITLA, J. C.-MONTALI, R. J.: Hematologic and serum chemistry values of captive scimitar-horned oryx (Oryx tao): Variations with age and sex. J. Zoo Anim. Med., 14, 1983: 51-55

DREVEMO, S. - GROOTENHUIS, J. G. - KARSTAD, L.: Blood parameters in wild ruminants in Kenya. J. Wildlife Dis, 10, 1974: 327-334

ELDIRDIRI, N. I. - SULIMAN, H. B.-SHOMMEN, A. M. : Normal serum activities of some diagnostic enzymes in Dromedary camel in Sudan. Vet. Res. Commun., 11, 1987: 201 - 203

GEORGIEVSKIJ, V. I. - ANNENKOV, B. N. - SAMOCHIN, V. T.: Minerálna výživa zvierat. Príroda, Bratislava, 1982: p. 432

POSPfŠIL, J.-PRADÁC, J.: Basic haematological and biochemical values in the peripheral blood of some exotic artio-and perissodacylids kept in East-Bohemia Zoological Garden in Dvưr Králové. Ưstav veterinární osvěty, Pardubice, 1984: p. 123 
POPfŠIL, J.-VÁHALA, J. - ŠPÁLA, P.-KAŠE, F.: Haematological and biochemical values in the peripheral blood of Cape Hunting Doge kept in the Eest-Bohemian Zoological Garden at Dvưr Králové nad Labem. Acta vet. Brno 56, 1987: 195-205

STOGDALE, L.: Correlation of changes in blood chemistry with pathological changes in the animal's body: II. Electrolytes, kidney function tests, serum enzymes, and liver function tests. J. South Afr. Vet. Assoc., 52, 1981: 155-164

VÄHALA, J. - POSPIŚIL, J. - ŚPALA, P. - KAŠ, F.: Biochemical blood serum values of healthy antelopes kept in the East-Bohemian Zoological Garden at Dvưr Králové nad Labem II. Alcelaphinae, Reduncinae, Antilopinae. Acta. vet. Brno, 58, 1989: 197-123 